\title{
IFMSS-Dedicated Issue Launched after 38th Annual IFMSS Meeting in Sils, Switzerland
}

\author{
Martin Meuli ${ }^{\mathrm{a}}$ Roland Zimmermann ${ }^{\mathrm{b}}$ \\ ${ }^{a}$ Department of Surgery, University Children's Hospital Zurich, Zurich, Switzerland; \\ ${ }^{b}$ Department of Obstetrics, University Hospital Zurich, Zurich, Switzerland
}

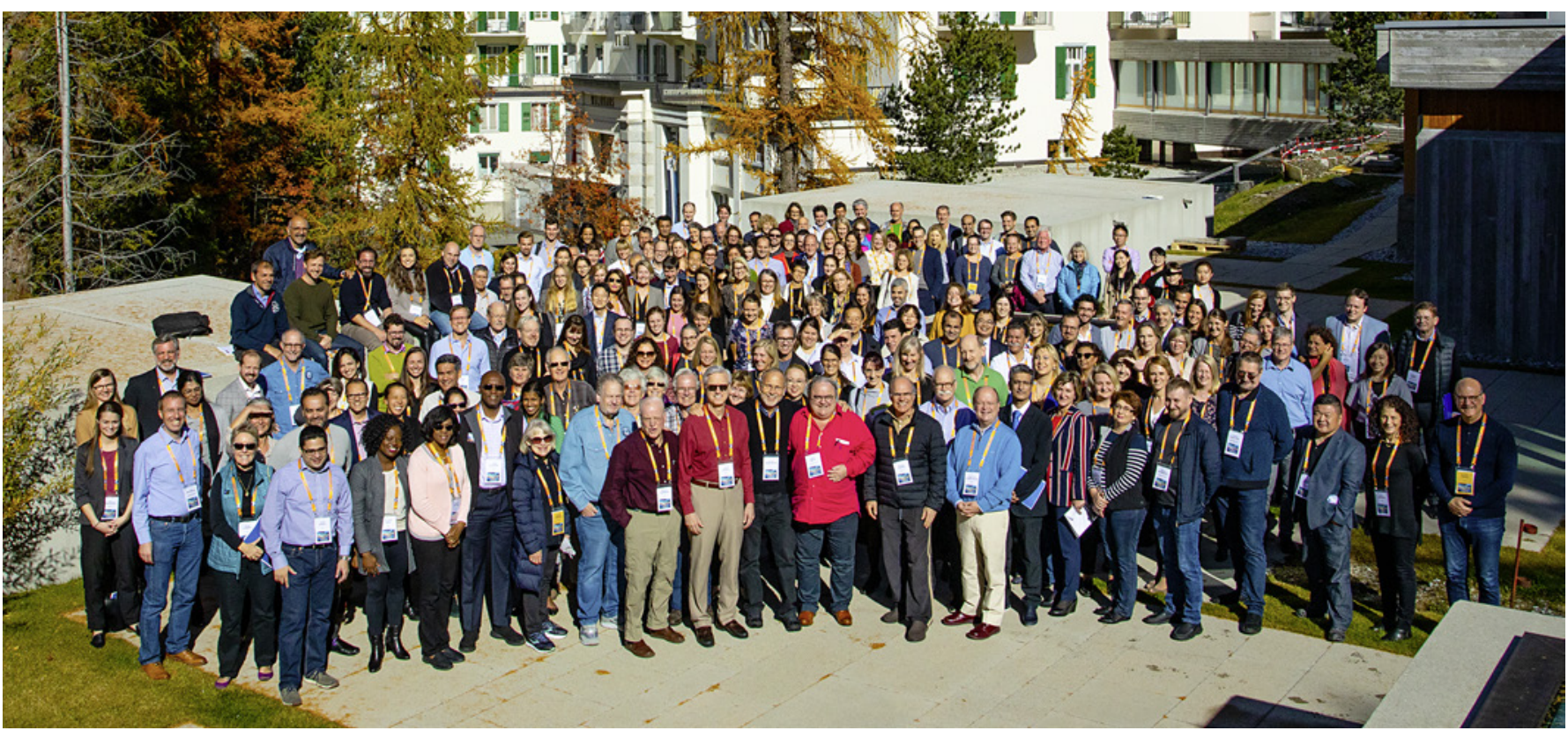

Dear IFMSS Members, dear colleagues and friends from Maternal Fetal Medicine, Pediatric Surgery, and all relevant specialties,

The International Fetal Medicine and Surgery Society (IFMSS) was founded in the year 1982 and has, subsequently, held an Annual Meeting every year since. In parallel, the Journal Fetal Diagnosis \& Therapy was started and initially run by IFMSS Members and so became the mother journal of the IFMSS.

karger@karger.com www.karger.com/fdt

Karger $\stackrel{2}{*}$ 马OPEN ACCESS
(C) 2020 The Author(s)

Published by S. Karger AG, Basel

This is an Open Access article licensed under the Creative Commons Attribution-NonCommercial-4.0 International License (CC BY-NC) (http://www.karger.com/Services/OpenAccessLicense), applicable to the online version of the article only. Usage and distribution for commercial purposes requires written permission.
To strengthen the ties between the IFMSS and FD\&T, it was decided among the IFMSS 2019 Congress Presidents Martin Meuli and Roland Zimmermann, the IFMSS Board, the Editor-in-Chief Eduard Gratacos, and Karger Publishers to create one additional issue of FD\&T per year to accommodate about a dozen papers presented at the IFMSS annual congress. The 2019 meeting took place from October 22 to 26 at the Hotel Waldhaus in Sils, Engadin, Switzerland. The group of 215 attendees and 57

Prof. Roland Zimmermann

Department of Obstetrics, University Hospital Zurich Frauenklinikstrasse 10

CH-8091 Zurich (Switzerland)

Roland.zimmermann@usz.ch 
accompanying persons, from all continents was able to fill the hotel Waldhaus, continuing our tradition of making the IFMSS an intense family environment. The scientific program comprised 158 oral presentations. The multifaceted social program can be revivified at https://www.ifmss2019.org/home/members-area/login.html.

We are extremely happy to present here the very first IFMSS-dedicated issue of FD\&T. A total of 24 manuscripts were submitted, and after regular peer review, we have selected the "Tower Lecture" and another 14 articles to be published. A good number of papers worth publication could not be included because of missing space.

We hope this premiere IFMSS-dedicated issue meets with good resonance and that it paves the way for a new, and soon to be traditional, way to reverberate highlights of future IFMSS Annual Meetings.

Martin Meuli,

Co-President IFMSS 2019, Associate Editor FD\&T Roland Zimmermann,

Co-President IFMSS 2019, Associate Editor FD\&T 